University of South Florida

DIGITAL COMMONS

@ UNIVERSITY OF SOUTH FLORIDA
Digital Commons @ University of

South Florida

$4-1-2004$

\title{
Public Transportation Syntheses Series: Fare, Free or Something in Between?
}

CUTR

Follow this and additional works at: https://digitalcommons.usf.edu/cutr_nctr

\section{Recommended Citation}

"Public Transportation Syntheses Series: Fare, Free or Something in Between?," National Center for Transit Research (NCTR) Report No. CUTR-NCTR-RR-2002-05, Center for Urban Transportation Research, University of South Florida, 2004.

DOI: https://doi.org/10.5038/CUTR-NCTR-RR-2002-05

Available at: https://scholarcommons.usf.edu/cutr_nctr/23

This Technical Report is brought to you for free and open access by the National Center for Transit Research (NCTR) Archive (2000-2020) at Digital Commons @ University of South Florida. It has been accepted for inclusion in Research Reports by an authorized administrator of Digital Commons @ University of South Florida. For more information, please contact digitalcommons@usf.edu. 
TITLE: FARE, FREE, OR SOMETHING IN BETWEEN?

October 2002 


\section{TITLE: FARE, FREE, OR SOMETHING IN BETWEEN?}

\section{ABSTRACT}

The following synthesis offers information as to the impact, cost, advantages, and disadvantages of implementing system wide fare-free policies in various transit systems. Information was gathered through the documented results of research done on case studies of fare-free experiments, and from active transit professionals with first-hand knowledge of the results of other fare-free demonstrations implemented by a variety of transit systems around the United States.

Based upon the findings of this synthesis, it is concluded that a fare-free policy might be appropriate for smaller transit systems in certain communities, but is ill-advised for larger transit systems in major urban areas because experience shows that in larger systems, a tremendous amount of criminal activity, as well as a sharp increase in ridership, caused higher maintenance costs, labor costs, and operational costs and drove away existing riders.

$\begin{array}{ll}\text { Authors: } & \text { Jennifer S. Perone } \\ & \text { Research Associate } \\ & \text { Center for Urban Transportation Research } \\ & \text { University of South Florida, CUT } 100 \\ & \text { 4202 E. Fowler Avenue, Tampa, FL } 33620 \\ \text { perone@cutr.usf.edu } & \\ & \text { (813) 974-9861 } \\ & \text { FAX: (813) 974-5168 } \\ & \text { Joel M. Volinski, } \\ & \text { Director, National Center for Transportation Research } \\ & \text { Center for Urban Transportation Research } \\ & \text { University of South Florida, CUT 100 } \\ & \text { 4202 E. Fowler Avenue, Tampa, FL 33620 } \\ \text { volinski@cutr.usf.edu } & \text { (813) 974-9847 } \\ \text { FAX: (813) 974-5168 }\end{array}$




\section{TITLE: FARE, FREE, OR SOMETHING IN BETWEEN? INTRODUCTION}

From time to time, either transit policy board members or transit managers seriously consider providing transit services free of charge to passengers. There are a number of factors behind the motivation to offer fare-free transit and there are consequences to any operational transit policy, and those who make decisions about whether to offer fare-free service should be aware of the range of possible consequences. There are many factors, which influence whether fare-free transit would be a negative or positive experience in any given environment such as the size of the community and transit system, degree of commitment to fare-free service by both the community and the transit system management and employees, and age and establishment of the transit service (16).

The purpose of this paper is to document the advantages and disadvantages of fare-free service in differing transit system environments within the framework of several fundamental policy questions.

\section{METHODOLOGY}

In researching fare-free policy, a search was initiated in TRIS Online and an exhaustive search of the Internet was performed, searching for all demonstrations of fare-free transit and the results of implementation of fare-free policy.

The internet was a valuable resource, but most articles pertained to decade old experiments. The fact that there have not been any recent fare-free demonstrations in larger transit systems is telling: After the disconcerting experiences of larger transit systems experimenting with fare-free service, most transit system directors were hesitant to try farefree service, instead opting for marketing to Universities and local employers for reduced fares to build ridership. This article focuses on the precise reasons why totally fare-free policies don't work in large metropolitan areas. 


\section{POTENTIAL ADVANTAGES OF FARE-FREE TRANSIT IMPLEMENTATION}

\section{Cost Advantages of Fare-Free Service}

The implementation of a fare-free policy may eliminate revenues collected, but it also eliminates costs associated with setting and collecting fares $(30,31)$. A certain amount of overhead is associated with fare policy research and planning within transit organizations. The elimination of fares could remove these costs and may free staff to focus on the quality and effectiveness of service, which is important in keeping and attracting quality ridership (33).

The impact of changes in transit fares on ridership is typically assessed by fare elasticity measures $(2,6$, 10, 22). The Simpson-Curtain Rule of fare elasticity would theoretically cause a 30 percent increase in ridership, with a 100 percent decrease in fares $(16,39)$. However, elasticity levels can vary by type of passenger, time of day, type of route, and length of time since the fare change was instituted $(6,22)$.

The farebox may be seen as a potential source of confusion and embarrassment to the uninitiated transit user (16). Although automobile users have costs over and above the cost of gasoline whenever they make a trip, they are not inconvenienced by having to search for change and remembering the confusing details of the transit system. Psychologically, this has a deleterious effect on existing and potential transit customers (39).

The types of ridership increases are also important. Hodge et al. (1994) propose that there are two positive sources of ridership change that can be accomplished by fare-free implementation:

- Transit riders who are attracted by the goal of decreasing auto use and fulfilling environmental objectives.

- Transit riders who are provided with additional mobility.

It has been found that smaller transit systems do not experience problem riders like those described in larger systems. Those organizations attribute these positive results to educational efforts and an aggressive, zero-tolerance policy for unacceptable behavior while on board transit (16).

\section{Positive effect of Fare-Free Policies on internal transit environment}

The removal of the farebox will change the vehicle environment. Proponents of fare-free service believe that removing the farebox will eliminate the problem of fare disputes and will also eliminate the abuse of drivers by passengers who equate fare payment with ownership of the vehicle. Much of the transit vehicle driver's job satisfaction is tied to interactions with passengers. If the farebox is removed and transit riders 
experience a more welcoming environment due to the removal of this potential psychological barrier, then the drivers will also benefit (16).

Some researchers (16) feel that critics have over emphasized the negative aspects of a fare-free policy, because problem riders are not always an issue, educational programs may resolve these problems, the severity of the problem riders may vary as a function of whether the system started fare-free or if the system converted, and management attitudes toward the fare-free policy and the communication of these attitudes to other transit employees may influence the agency's fare-free experience.

\section{System efficiency- Advantages in a fare-free system}

Traditionally, one measure of system effectiveness is the farebox recovery rate. In support of fare-free service, researchers (16) state that an overemphasis on farebox recovery is counterproductive with respect to the goal of increasing ridership. Instead, system effectiveness could be measured by cost per rider, rather than farebox recovery. In the case of Austin, Texas, in the 12 months prior to the fare-free experiment, the average cost per rider was $\$ 2.51$. During the 15 months of the fare-free experiment, the average cost per rider was $\$ 1.51$ and rose back up to an average cost per rider of $\$ 2.18$ in the year following the fare-free experiment (5). Researchers (16) purport that the system also gained some efficiencies because there were no labor and capital expenses associated with collecting fares.

\section{Community image advantages}

In current U.S. culture, public transit is most often viewed as the option of last resort. Existing users may view transit differently from non-users of transit. In many cases, automobile users view any increase in taxes that fund transit as being unfair to them, not realizing that society subsidizes auto travel (39). In a fare-free transit system, people who usually drive may be encouraged to use public transit simply because it does not cost them anything more to use public transit.

\section{POTENTIAL DISADVANTAGES OF FARE-FREE TRANSIT IMPLEMENTATION Cost Disadvantages of Fare-Free Service}

In larger transit systems, fareboxes generate much more of an agency's operating revenue than smaller systems. At Miami-Dade Transit, fareboxes generate $\$ 70$ million per year (or 33.33 percent) of the approximately $\$ 210$ million in operating costs (25). Comparatively, in many smaller systems the farebox recovers less than ten percent of the yearly operating cost. Removing the farebox might make fiscal sense in smaller systems because the costs associated with farebox collection and farebox maintenance may equal the fare revenue. However, in larger transit systems, the actual cost of removing the fareboxes will leave the system with a very large revenue shortfall. 
Although the Mercer County (Trenton, NJ) fare-free demonstration in 1979 was conducted only during non-peak hours, their system sustained a loss in peak hour fares as well. A total of one-fourth (24.7 percent) of their revenue was lost from the fare-free experiment, with 4.3 percent of that loss coming from fare revenue lost during peak transit hours. Additionally, Mercer Metro had to provide additional bus service to meet excessively high passenger demands during the fare-free hours, causing operation costs to skyrocket (9).

The Capital Metro fare-free experience in Austin, Texas mirrors the Mercer Metro results. The system quickly became overburdened with requirements for capacity expansion and a subsequent increase of operating costs. The skyrocketing operation and maintenance costs became a substantial drain on the system. Officials at Capital Metro described the cost of operation in a fare-free system as "staggering" (29).

\section{Negative effect on internal transit environment}

Fare-free systems can attract problem riders, resulting in vandalism and problems for other riders. The Miami Beach Transportation Management Association sponsors electric shuttle bus service in Miami Beach. For the first year of operations, the service was offered for free. This new service attracted over a million riders in its first year, with only seven buses in operation. However, the free fares also attracted undesirable passengers.

The absence of fares can make riders feel a lack of responsibility for the well being of the transit system, also resulting in a negative impact on driver satisfaction. In the Trenton, New Jersey fare-free experiment, 92 percent of transit drivers found their jobs to be less enjoyable as a result of the fare-free program (9). In the Austin, Texas experiment, officials claim that transit operators came close to "insurrection" as their transit system became flooded with truant school children, vagrants, and other "dubious categories" of passengers (29). It is important to note that these findings contradict the findings by Hodge et al. (16) that eliminating the fare would result in a more positive environment for transit vehicle operators because they wouldn't have to argue with passengers over fares. However, the psychological barrier of the farebox and hunting for change and dealing with paper transfers could be minimized with new fare structures (e.g., an all-day pass) or new farebox technology, which would eliminate transfers and accept stored-value cards or even credit cards.

However, psychological costs in personal security and physical crowding seen in these fare-free demonstrations may actually cause more problems than the psychological cost of the farebox. Problem riders increase personal security costs of transit use and cause a decrease in ridership of both new and existing quality riders (16). As evidenced in the Austin experiment, quality riders do not immediately return 
to the system once they've been driven out, and the system must prove itself over time to disenfranchised riders (29). Steiner and Starling (32) claim that eliminating the farebox may cause a decrease in average boarding times, but it will cause an increase in aggregate boarding times. The reality is that increased ridership will result in more crowding, which will negatively impact boarding times. Additionally, schedule adherence will be negatively impacted by a larger number of people riding the bus short distances who might have otherwise walked (32).

As mentioned previously, the transit industry standard for measuring increase in ridership is fare elasticity (16). However, elasticity estimates do not take into account the impact that system-wide fare-free implementation can have on encouraging problem riders and what ramifications that might have on longterm riders. A farebox may be seen as a psychological barrier to the new transit user, but it may also be a barrier in keeping out a less desirable type of transit rider. According to Hodge et al.(16), there are two negative sources of ridership change, which can possibly overwhelm a system and drive away quality ridership:

- Transit riders who would have used other modes, but choose transit because it is free

- Transit riders who enter the system for the negative and criminal purposes.

In the Austin, Texas fare-free demonstration, both anecdotal and official data suggest that problem riders increased substantially and drove away other riders. In both the Mercer Metro and the Austin, Texas experiences, problem riders actually drove away many of the regular bus commuters. In none of the experiments did the increase in transit ridership include automobile commuters enticed by the fare-free service $(9,20,29)$.

\section{System efficiency-Disadvantages in a fare-free system}

System effectiveness can be measured by the farebox recovery rate. Fare-free advocates suggest that system effectiveness could instead be measured by per rider cost. In another example, consider a fairly large transit system that moved approximately 270,000 riders per day. If that system experienced a 30 percent increase in ridership due to fare-free program implementation, it would have an increase of approximately 81,000 riders per day, based on fare elasticity analysis. A caveat here: As the fare approaches zero, there may be changes around zero which are not accounted for by the Simpson-Curtain rule of fare elasticity. Based upon the information from both Mercer Metro (Trenton, New Jersey) and Capital Metro (Austin, Texas), most transit systems could not recover from such a loss of revenue, even if the system might be regarded as more efficient on a cost-per-passenger basis. Imagine that the system becomes overwhelmed with passengers, and must provide expansion of service. Also imagine that the system must now pay for maintaining the system in the face of vandalism and property damage from 
problem passengers, as well as hiring off-duty police officers to control security incidents. Without passenger-generated revenues, most transit systems would be unable to pay for additional services and quality of service will suffer.

\section{Community image disadvantages}

If fare-free transit is implemented and the system becomes inundated with problem riders, vandalism, and personal crimes, the system will be viewed negatively and quality riders will not be attracted to it. In trying to remove barriers that separate the transit-dependent rider from the quality rider, such as removing the farebox, the transit system may instead have unwittingly erected other barriers which are far more damaging to the image of the system. Problem riders who may be encouraged into the system by a farefree policy may damage the system's public image, as well as damage the system physically and financially. Given these very serious repercussions, care must be taken in assessing if fare-free policies would be beneficial or detrimental to a particular system and community.

\section{CASE STUDIES}

\section{Temporary Fare-Free Experiments}

Two of the largest fare-free demonstrations were conducted in the late 1970s in Trenton, New Jersey and Denver, Colorado. Both projects lasted slightly more than one year between 1978 and 1979, and were implemented on an off-peak basis. In Trenton, the primary motivation for the experiment was social and economic redevelopment of the area. In Denver, the primary motivation for the experiment was reducing pollution and automobile use (16). The Denver experiment resulted in a 36 percent increase in ridership and the Trenton experiment resulted in a 16 percent increase in ridership (11).

Many fare-free advocates express concern with the methodology of these two experiments, the first being that both experiments were run during off-peak hours only. If the motivation was to promote transit use and reduce congestion, then perhaps the experiments should have been run during peak periods (16).

A medium-sized transit system that experimented with total fare-free service was Austin, Texas. The experiment ran from October 1989 to December 1990. Ridership increased 75 percent during the experiment, but expanded service accounts for some of this percentage (5), and the People for Modern Transit (PMT) Technical Committee (29) claims that once the ridership increase is adjusted for normal growth and addition of University of Texas student passengers, the initial jump really only amounted to a 10 percent increase. This experiment was regarded as both successful in terms of increasing ridership and disastrous in terms of attracting problem riders who drive away quality ridership and caused system losses due to criminal activity (29). In response, 75 percent of transit drivers petitioned to have the farefree program discontinued immediately, due to the abuse they were experiencing at the hands of problem 
riders (20).

When summing up the experience of these fare-free demonstrations:

- All systems showed a substantial ridership increase (ranging from $13 \%$ to $83 \%$ )(16);

- There is little evidence that these projects made a significant dent in Single Occupant Vehicle travel during peak hours $(5,28,33)$;

- While the community at large supported fare-free policies, actual riders complained about deterioration of safety and service quality;

- Bus operators voiced concerns over increased rowdiness, problem passengers, and the effect on schedules $(20,39)$.

\section{PERMANENT FARE-FREE TRANSIT SYSTEMS}

The oldest fare-free system is located in Commerce, California, just outside of Los Angeles. This system has operated fare-free since 1962. According to the manager of this system, they do not experience problems with riders other than occasional graffiti (16). However, this is a very small system, serving approximately 970,000 riders annually with 11 buses. Although this system is located only six miles outside of Los Angeles, transit officials tell us that since they have such a limited travel area, they do not attract problem riders (8).

The next oldest system is located in Amherst, Massachusetts and has been providing fare-free service since 1976. The Amherst, Massachusetts system is free to all, but is partially funded by a yearly student fees. This system serves five colleges in the area and also the surrounding communities. It serves approximately 6 million passengers every year and operates approximately 40 buses (37). This type of service is in place at many universities throughout the country, and seems to be relatively problem-free.

Island County Transit, located in Washington State, has operated a fare-free system since its inception in 1987. According to Director Martha Rose, Island County Transit has a low occurrence of problem passengers. It has 16 fixed-route buses and 2 paratransit buses. They serve 675,775 passengers per year on their fixed-route service and 19,664 passengers annually on their paratransit routes (18). Rose attributes their success with a three-strikes policy and also to educational programs in the schools. The only complaints noted for this system were the need for more park and ride lots and buses to deal with increasing ridership demands.

It is important to note that all of the permanent fare-free systems listed above started out as fare-free systems and are either small systems, or serve limited populations (e.g., UMass serves a community with 
five colleges). In addition, all of the successful fare-free systems shown in this synthesis serve small cities or rural areas.

\section{SUMMARY AND RECOMMENDATIONS}

In order to assess if a fare-free policy would benefit a transit system, there are several questions that must be addressed:

- What is the net cost of a fare free policy?

In smaller systems, the net farebox recovery is usually less than ten percent (14). The cost of collection might cancel out any net proceeds of fare collection. Most systems operating in smaller communities do not experience the same types of problem riders experienced in larger, more metropolitan areas.

In larger systems, the net farebox recovery is typically much greater than smaller systems, and the revenue is a substantial portion of the operating budget. As evidenced by the Capital Metro fare-free experiment in Austin, Texas, which only had a 15 percent farebox recovery, the ballooning costs of operations due to maintenance, labor, and security costs financially threatened the well being of the system. The cost of the deterioration of the internal bus environment, security, employee satisfaction, and public image was definitely not worth any benefits that could be gained by farefree $(20,29)$.

- What will be the impact of a fare-free policy on ridership and quality of service?

Fare-free policy will yield substantial gains in ridership. What is important is the type of ridership that is being gained. Will the types of people attracted to the system be positive or negative for the system? Will the implementation of fare-free service overwhelm the system with overcrowding and problem riders, driving away existing users?

- How will a fare-free policy impact the attainment of the community's goals?

Will fare-free service increase mobility for transit-dependent riders in the community? Will fare-free service advance environmental and traffic congestion goals? Will fare-free service cause a positive perception of the transit system in the long term? Will fare-free service cause an increase or decrease in customer service and satisfaction?

It seems that fare-free service in certain communities with smaller transit systems can be a positive experience, as evidenced by long-running fare-free services in systems such as Commerce, California; Amherst, Massachusetts; and Island County Transit in Washington. However, the experience with farefree service in large urban areas has not been successful in terms of overall service quality. Fare-free 
proponents question the methodology within these fare-free demonstrations: two of the larger systems discussed in this report (Denver and Trenton) offered the fare-free service during peak transit hours only. It is not clear if more ridership might have been attracted during peak hours. It could be that off-peak times actually attract more problem riders, while not assisting in the attainment goals such as promoting transit use, increasing mobility, and reducing traffic congestion and pollution.

In the case of Austin, Texas, fare-free service was provided all day, and there were no time limits set on the demonstration. Although significant efforts were made to increase passenger safety and comfort through hiring off-duty police officers, Hodge et al. (16) claim that many of the Austin demonstration's problems stemmed from lack of support for the policy from agency managers and lack of planning and scheduling for overload on specific routes. Many others point to the fact that a fare-free policy simply overwhelms the system, significantly increasing operating costs. The fare-free experiment did not increase quality ridership or improve the public image of the system and problem riders were attracted to the system, and vandalism and crime increased (29). Physical assaults tripled in the first three months of the fare-free implementation, increasing to 120 incidences from 44 in the three months prior to implementation (3). Many faithful riders were driven from the system by fear for personal safety and the deterioration of the bus environment and they were not quick to return after the experiment $(20,29)$.

Fare-free proponents (16), who espouse the benefits of fare-free policy stop short of recommending farefree implementation for larger systems. They instead advocate achieving better system efficiency and quality ridership via marketing of prepaid fares. If a transit system is trying to attract a certain type of rider with the incentive of fare-free service, why not market the fare-free service directly to that population? A transit system might market passes to surrounding businesses and universities on a prepaid basis. Prepaid fare marketing to choice rider populations would seem to be a more efficient way of increasing choice ridership, increasing mobility, and decreasing traffic congestion and pollution. Issues such as safety, travel time, frequency and reliability of service, availability and ease of schedule and route information, infrastructure at stops, and driver courtesy, were all found to be more important than the cost of fares (39).

In a study performed in the Spring of 1990, during the fare-free demonstration period, Capital Metro (5) asked both riders and the general public for the five most important factors in determining whether to ride the bus. The five most important factors were:

\section{- On-board safety}

- On-time performance 
- Convenience of routes

- Cleanliness inside the buses

- $\quad$ Frequency of service (5).

The three least important factors in determining if both riders and the general public would ride the bus were:

- Cost of service;

- Outside appearance of the buses;

- Courtesy of the bus operators (20).

Transit systems desiring to increase choice ridership should instead focus on improving service quality and safety for customers. Even a minimum fare offers a barrier to problem riders that cause a deterioration in the service, image, and comfort of a given transit system $(6,39)$.

\section{NEW DIRECTIONS}

There are many unanswered questions in the presented research review. Are fare-free demonstrations really a bad idea? Or, has the proper research not yet been done? There have been many research projects into increasing ridership by marketing to certain demographics via schools or employers. There are successful U-PASS programs, which offer unlimited transit service to students in many other University communities $(4,24,35,38)$. While these programs are not fare-free in the truest sense, they allow students, staff, and faculty a complete package of transportation benefits for a very low price, while building ridership on the transit system. In fact, in the Chicago area, the U-PASS program accounts for one-sixth of the Chicago Transit Authority's (CTA) ridership (35).

There are questions that linger here that need to be addressed. Can the results of any of the urban transportation fare-free demonstrations be trusted? Did the fare-free experiments fail because fare-free doesn't work in larger systems, or did it fail because staff members of larger transit systems had negative feelings about the demonstration? Elimination of fares has been theorized to help increase transit system efficiency by reducing the cost of fare collection (30,

31). For fairness, future directions in fare-free demonstrations in larger urban settings should 
include better controls of the attitudes of staff and directors in those systems. It is possible that predetermined attitudes contributed to the failure of fare-free demonstrations in larger transit systems. Future studies should include comprehensive studies of farebox recovery in smaller versus larger systems and which amenities are most important to riders.

\section{REFERENCES}

1. Arndt, Jeff, Vice President and Chief Operating Officer of Metro in Houston, Personal Email Communication, February $4^{\text {th }}, 2002$.

2. Baum, H.J. (1973). Free Public Transport. Journal of Transport Economics and Policy, 7(1), 319.

3. Brooks, A.P. (1990). Cap Metro Warned of Risk of Crime Since Free Fares. Austin AmericanStatesman, March 27, 1990.

4. Brown, J., Hess, D. \& Shoup, D. (2003). Fare-Free Public Transit at Universities: An Evaluation. To be published in The Journal of Planning and Education Research. Pre-print March $5^{\text {th }}, 2003$. pp. 1-27.

5. Capital Metro. (1989-1991). Quarterly Reports.

6. Cervero, R. (1990). Transit Pricing Research: A Review and Synthesis. Transportation, 17(2), 117-139.

7. Chung, Frances, Director of Financial Services for GO Transit in Toronto, Canada, Personal Email Communication, January $29^{\text {th }}, 2002$.

8. City of Commerce Transit. (2002). Personal Communication Regarding Number of Passengers and Transit Vehicles.

9. Connor, D.L. (1979). Findings of Preliminary Analyses of the Trenton, New Jersey Off-Peak FareFree Transit Demonstration. A report prepared for the U.S. DOT by DeLeuw, Cather, \& Company.

10. Doxsey, L.B. (1980). Elasticity Measures of Behavioral Response to Off-peak Fare-free Transit. Transportation Research Board, N761, 7-14.

11. Doxsey, L.B., \& Spear, B.D. (1981). Free-fare Transit: Some Empirical Findings. Transportation Research Board, N799, 47-49.

12. Evans, Judy, Director, Miami Beach Transportation Management Associates, Personal Communication July $9^{\text {th }}, 2002$.

13. Foote, Peter, Project Oversight Coordinator for Chicago Transit Authority, Personal Email Communication, January $29^{\text {th }}, 2002$ and Personal Telephone Communication, July $24^{\text {th }}, 2003$.

14. Gregg, R., Joslin, A., Mistretta, M., \& Morris, W. (2002). Planning Assessment Program for Florida Public Transit: Planning and Funding Perspective. A report prepared for the Florida Department of Transportation, FDOT project \# BC896, CUTR Project \# 2117-438LO.

15. Hay, A.M. (1984). The subsidy of urban public transportation, in D.T. Herbert \& R.J. Johnson 
(eds.). Geography and the Urban Environment, New York: John Wiley and Sons.

16. Hodge, D.C., Orrell III, J.D., \& Strauss, T.R. (1994). Fare-free Policy: Costs, Impacts on Transit Service and Attainment of Transit System Goals. Report Number WA-RD 277.1. Washington State Department of Transportation.

17. Hughes, Lawrence, Director of Service Development for Green Bus Lines and TRB Bus Transit Systems Committee Member, Personal Email Communication, January $29^{\text {th }}, 2002$.

18. Island County Transit. (2002). Personal communication regarding number of passengers and transit vehicles.

19. Kemp, Michael, Consultant for Charles Rivers and Associates, Personal Email Communication, January $29^{\text {th }}, 2002$.

20. Kounes, A.M. (1993). Memorandum: An Assessment of Fiscal, Ridership, and Operational Impacts of Reintroducing a Free-Fare Policy in 1994, August $17^{\text {th }}, 1993$. Prepared for the Chairperson and Members of the Board of Directors.

21. Kravif, Diane, Transit consultant and Leadership APTA member, Personal Email Communication, January $30^{\text {th }}, 2002$.

22. Lago, A., Mayworm, P.D., \& McEnroe, J.M. (1981). Further Evidence on Aggregate and Disaggregate Transit Fare Elasticities. Transportation Research Board, N799, 42-47.

23. Lange, Jeff, TRB Bus Transit Systems member, Personal Email Communication, January $29^{\text {th }}$, 2002.

24. Meyer, J. \& Beimboom, E. (1998). Usage, Impacts, and Benefits of an Innovative Transit Pass Program. Transportation Research Record 1618, TRB, National Research Council, Washington, D.C., pp. 131-138.

25. Miami-Dade Transit. (2002). Personal communication regarding fare and revenue structure.

26. Miller, J. (2001). Transportation on College and University Campuses, Transportation Cooperative Research Program Syntehsis 39, Washington, D.C.: National Academy Press.

27. Olsen, D. (2000). Fare-free Transit Would be More Than Fair, April $3^{\text {rd }}, 2000$. http://www.nsnews.com/issues00/w040300/othervoices.html

28. Pence, R. (2003). Free buses do NOT help traffic congestion. http://www.peoplefor moderntransit.org/Articles/Frbu021601_Cont.html.

29. PMT Technical Committee. (2001). Fare-free buses. http://www.peopleformoderntransit.org/Articles/Frbu010001_Cont.html.

30. Scheiner, J.I. (1976). Exploding the Myths of Prepaid Transit. Transit Journal, 2(1), 57-64.

31. Scheiner, J.I. \& Mundle, S.R. (1978). Cost Analysis of Current U.S. Surface Transit Fare Collection Systems., Transportation Research Board, N663, 60-62.

32. Scheiner, J.I. \& Starling, G. (1974). The Political Economy of Free-fare Transit. Urban Affairs Quarterly, 10(2), 170-184. 
33. Sims, R. (2001). Ride-free Buses are not the Answer to Traffic Woes, February $15^{\text {th }}, 2001$. http://seattlepi.nwsource.com/opinion/simpsop4.shtml.

34. Stitcher, Joe, Deputy Director of Santa Monica's Big Blue Bus, Personal Email Communication, January 29 2002.

35. Stuart, D.G. (2001). University and College Ridership Growth in Chicago: U-Pass Program. Paper presented at the American Public Transportation Association's Rail Transit Conference, Boston, MA, June $10^{\text {th }}-14^{\text {th }}, 2001$.

36. Studenmund, A.H., Swan, S., \& Connor, D. (1979). Interim Analysis of the Free-fare Transit Experiment. Transportation Research Board, N719, 13-21.

37. UMass Transit, Amherst, Massachusetts. (2002). Personal communication regarding number of passengers and transit vehicles.

38. Williams, M.E. \& Petrait, K.L. (1993). U-Pass: A Model Transportation Management Program that Works. Transportation Research Record 1404, TRB, National Research Council, Washington, D.C., pp. 73-81.

39. Yaden, D. (1998). Fareless Transit in the Portland Metropolitan Region, A Report of the Fareless Transit System Research Workgroup prepared for Portland, OR Mayor Vera Katz by Parsons, Brinkeroff, Quade, \& Douglas, Inc. 